Francisco Javier Candel ${ }^{1,2}$

Jesús Canora ${ }^{1,3}$

Antonio Zapatero ${ }^{1,4}$

Raquel Barba ${ }^{1,5}$

Juan González del Castillo 1,2

Gonzalo García-Casasola ${ }^{1,6}$

Jesús San-Román ${ }^{1,7}$

Ruth Gil-Prieto ${ }^{1,7}$

Pablo Barreiro ${ }^{1,8}$

Marcos Fragiel 1,2

Fernando Prados ${ }^{1,9}$

Pablo Busca ${ }^{1,10}$

Jesús Vázquez-Castro ${ }^{1,11}$

Javier Marco ${ }^{1,2}$

\section{Temporary hospitals in times of the COVID pandemic. An example and a practical view}

\author{
'COVID-19 IFEMA temporary Hospital. \\ ${ }^{2}$ Hospital Clínico Universitario San Carlos. Madrid. Spain. \\ ${ }^{3}$ Hospital Universitario de Fuenlabrada. Madrid. Spain. \\ ${ }^{4}$ Medical Manager IFEMA temporary Hospital. Madrid. Spain. \\ ${ }^{5}$ Hospital Universitario Rey Juan Carlos. Madrid. Spain. \\ ${ }^{6}$ Hospital Universitario Infanta Cristina. Parla. Spain. \\ ${ }^{7}$ Medical Specialties and Public Health Department. Rey Juan Carlos University. Madrid. Spain. \\ ${ }^{8}$ Hospital Universitario La Paz. Madrid. Spain. \\ ${ }^{9}$ Emergencies SAMUR. Madrid. Spain. \\ ${ }^{10}$ Emergencies SUMMA 112. Madrid. Spain. \\ ${ }^{11}$ Primary Health Care Management. Madrid. Spain.
}

\section{Article history}

Received: 7 March 2021; Revision Requested: 10 March 2021; Revision Received: 14 March 2021; Accepted: 15 March 2021; Published: 22 March 2021

\section{ABSTRACT}

We describe the most widely used temporary hospital in Europe during the first pandemic wave, its structure, function, and achievements. Other models of care developed during the pandemic around the world were reviewed including their capacity, total bed/ICU bed ratio and time of use. We particularly analyzed the common and differential characteristics of this type of facilities. IFEMA Exhibition Center was transformed into a temporary 1,300-bed hospital, which was in continuous operation for 42 days. A total of 3,817 people were treated, generally patients with mild to moderate COVID-19, 91\% of whom had pneumonia. The average length of stay was 5 to 36 days. The most frequent comorbidities were hypertension (16.5\%), diabetes mellitus (9.1\%), COPD (6\%), asthma (4.6\%), obesity (2.9\%) and dementia (1.6\%). A total of 113 patients $(3 \%)$ were transferred to another centers for aggravation, 19 (0.5\%) were admitted to ICU and 16 patients (0.4\%) died. An element of great help to reducing the overload of care in large hospitals during peaks of health emergencies could be these flexible structures capable of absorbing the excess of patients. These must be safe, breaking domestic transmission and guarantee social and emotional needs of patients. The success of these structures depends on delimitation in admission criteria taking into account the proportion of patients who may require, during admission, assistance in the critical care area.

Key Words: Temporary hospital; COVID-19; emergence facilities; hospital design; admission criteria; ICU beds.

Correspondence:

Francisco Javier Candel

Clinical Microbiology and Infectious Diseases.

Hospital Clinico Universitario San Carlos. Madrid. Spain.

E-mail: franciscojavier.candel@salud.madrid.org
Hospitales temporales en tiempos de pandemia de COVID. Un ejemplo y una visión práctica

\section{RESUMEN}

Describimos el hospital temporal más utilizado en Europa durante la primera ola de la pandemia, su estructura, función y resultados, así como otros modelos de atención desarrollados durante la pandemia en todo el mundo. Se revisa su capacidad, ratio de camas totales/UCl y tiempo de uso. También se describen las características comunes y diferenciales de este tipo de instalaciones. El recinto ferial de IFEMA se convirtió en un hospital temporal de 1.300 camas, que estuvo en funcionamiento continuo durante 42 dias. Se atendió a un total de 3.817 personas, en general pacientes con COVID-19 leve a moderada, de los cuales el 91\% tenía neumonía. La duración media de la estancia fue de 5 a 36 días. Las comorbilidades más frecuentes fueron la hipertensión (16,5\%), la diabetes mellitus (9,1\%), la EPOC (6\%), el asma (4,6\%), la obesidad $(2,9 \%)$ y la demencia (1,6\%). Un total de 113 pacientes (3\%) fueron trasladados a otros centros por agravamiento, $19(0,5 \%)$ fueron ingresados en la $\mathrm{UCl}$ y 16 pacientes $(0,4 \%)$ fallecieron. 1200 camas totales con un $8 \%$ de camas críticas podria ser una proporción óptima, pero delimitando los criterios de ingreso. La clave para reducir la sobrecarga asistencial en los grandes hospitales durante los picos de emergencias sanitarias reside en estas estructuras flexibles capaces de absorber el exceso de pacientes. Estas deben ser seguras, romper la transmisión doméstica y garantizar las necesidades de atención social y emocional de los pacientes. El éxito de estas estructuras depende de la delimitación en los criterios de admisión teniendo en cuenta la proporción de pacientes que pueden requerir, durante el ingreso, asistencia en el área de cuidados críticos..

Palabras Clave: Hospital temporal; COVID-19; instalaciones de emergencia; diseño de hospitales; criterios de admisión; camas de UCI. 


\section{INTRODUCTION}

Since December 2019, infection caused by Severe Acute Respiratory Syndrome Coronavirus-2 (SARS-CoV-2), named as Coronavirus Infectious Disease-19 (COVID-19) [1], has acquired pandemic dimension resulting as of January 27th, 2021 in more than 100 million cases and in more than 2 million deaths in 223 countries [2]. In Spain, as in Italy, the pandemic has struck extremely hard [3] from mid-March 2020, forcing the authorities to adapt the healthcare structure to attend the incoming burden of infected patients. The Community of Madrid is a central and populated Region of 6.7 million people in Spain. It has 36 public hospitals with 15,277 hospital-beds (ratio of 277.1 beds per 100,000 inhabitants) in a country that offers 297.29 beds per 100,000 people [4]. However, Madrid has the availability of 692 intensive care unit (ICU) beds, with a medium occupancy rate of 60\% [5]. Despite the large number of health resources available in the Region, during the third week of March 2020, when cases of COVID-19 began to increase exponentially, the number of patients began to exceed the capacity in most hospitals. The Emergency Services were close to collapse, admitting nearly 3,500 patients in a short period of time.

Given this situation and after on the previous experienced from Wuhan, China [6], the health authorities in the Community of Madrid raised the possibility of creating a temporary health-care structure to address this emergency. A large space was necessary, with the flexibility to modify spaces to relocate patients and thereby decongest the emergency services. This was achieved by reconverting the International Fairground Exhibition Center in Madrid (IFEMA). It was carried out in record time. Our main aim was to select and capture patients diagnosed with COVID-19 who could be safely cared for at IFEMA by optimizing admission criteria and ensuring their transfer. The second was to analyze the ratio of intermediate and ICU beds to treat the respiratory deterioration of our admitted patients. This needed to be done urgently, given the impending collapse of our health system. Meeting this objective required working on the healthcare front while developing the entire structure. In this manuscript the authors describe the structure and function of the most used temporary hospital in Europe during the first pandemic wave. It also reviews other care structures used.

\section{PLACE AND STRUCTURE}

IFEMA has $200,000 \mathrm{~m}^{2}$ of covered exhibition space in twelve halls, a Convention Center of more than 10,000 m², as well as spaces, facilities and 14,000 parking spaces. The center is situated in the Northwestern area of the city, close to Barajas airport and between the $\mathrm{M}-11$ and $\mathrm{M}-40$ motorways. Characteristics of each hall are detailed in Figure 1. Temporary medicalized structures were built in three of these halls, one provisional (Hall 5) and two long-lasting (Halls 7 and 9) (Figure 1). We used another hall as a warehouse. The main need in the care of COVID-19 patients was the high requirement of oxygen, to ensure optimal ventilatory therapy of all patients admitted. The consumption of oxygen bottles was extremely

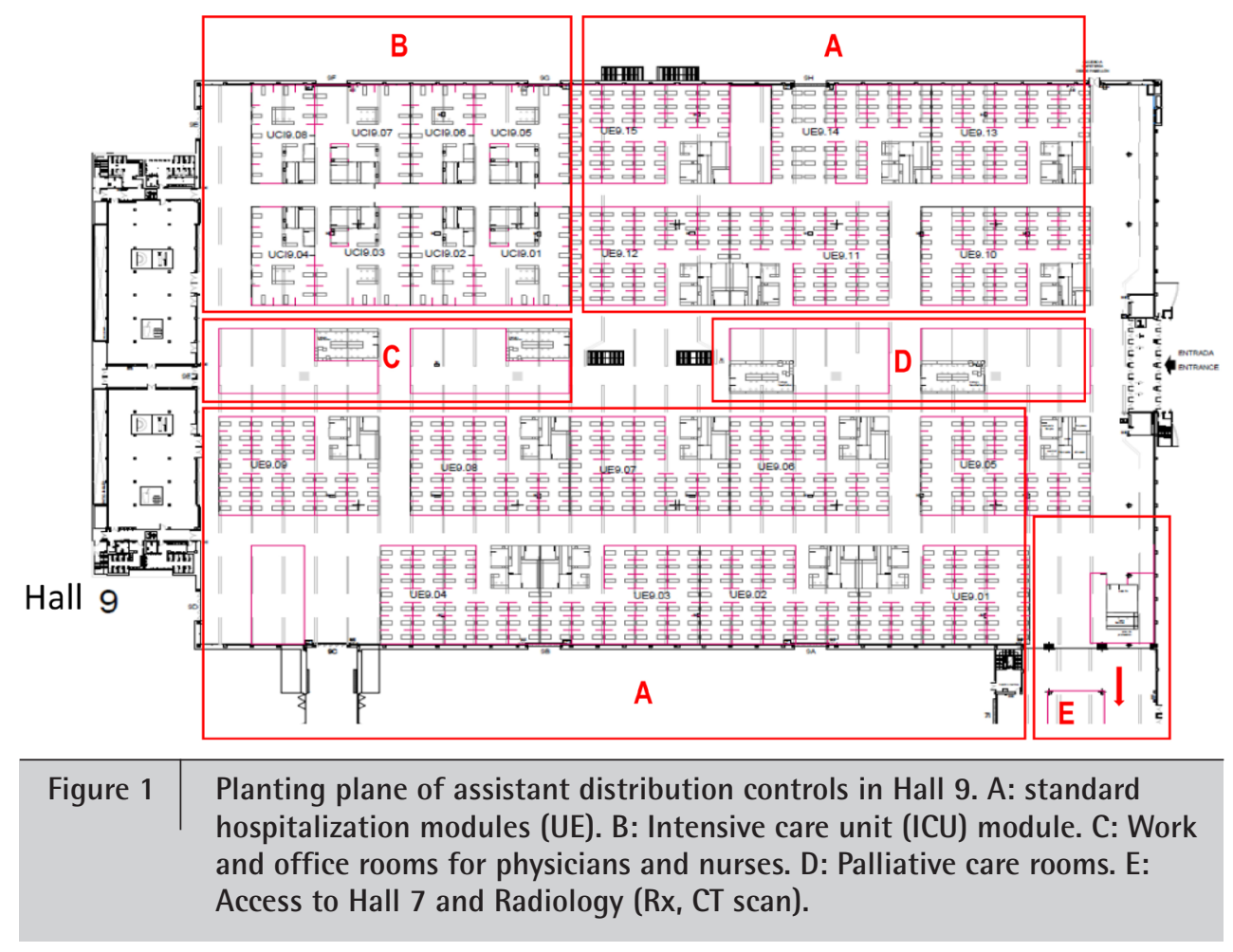


A
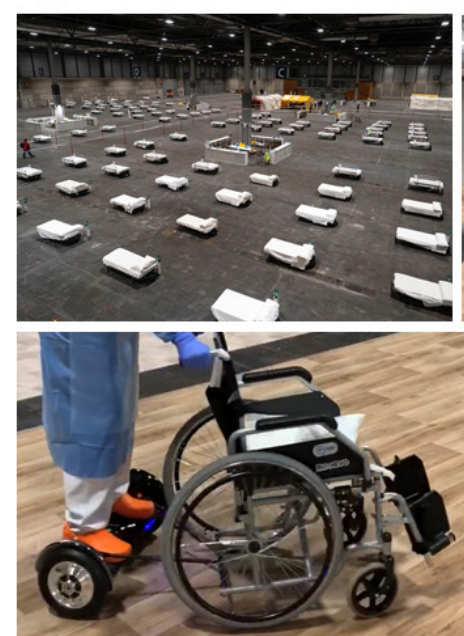

E
B
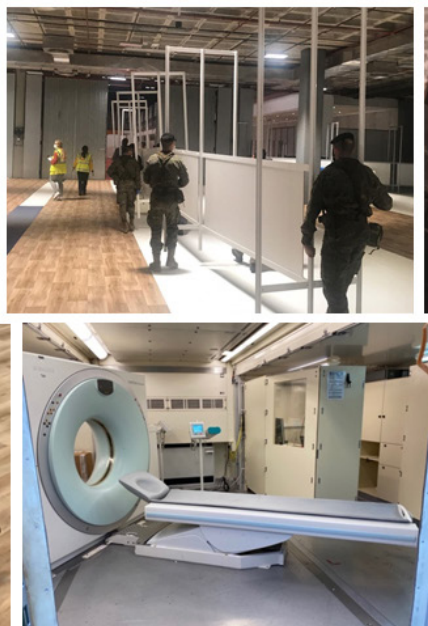

$\mathrm{F}$ c
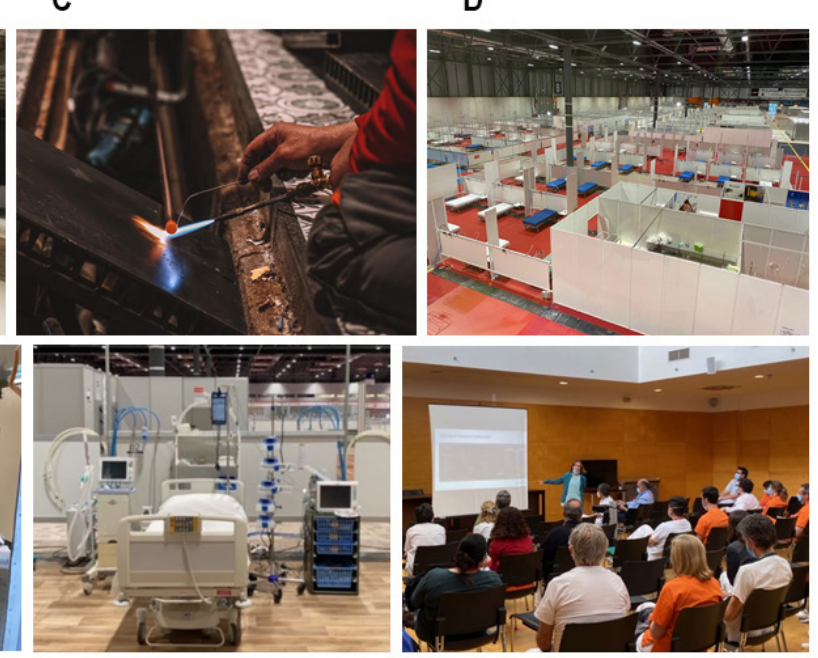

G

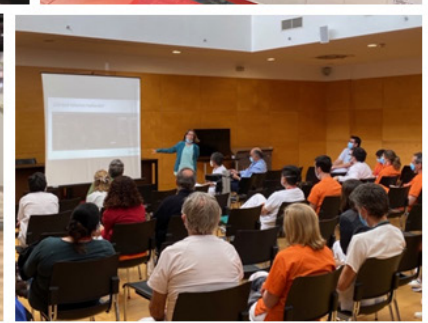

H

Figure 2 A: Distribution of beds in ward 5 at the beginning (first week). B: Transition to ward 9 with army in the assembly of panels and the structure. C: A total of twenty-seven kilometers circuit of soldered copper tube were connected to external oxygen towers. D: Final Aspect of Hall 9, ready to admittance. E: hoverboard devices connected to wheelchairs for transporting patients and pharmaceuticals. F: Portable CT scan. G: Intensive care bed. H: Continuous training sessions updating protocols of action.

high and often insufficient, and some patients suffered desaturations because their bottles were depleted. To guarantee ventilatory support, more than $25 \mathrm{~km}$ of soldered copper tube circuit were installed and connected to external oxygen towers. This operation was completed in 72 hours. Alternative ventilation devices in pre-critical patients were also developed to guarantee positive expiration pressures through CPAP systems or modified masks [7].

The assembly of Hall 9, with a capacity of 750 beds, began simultaneously with that of Hall 5. This space was designed to have a structure more like a conventional hospital. It consisted of 15 nursing controls with a capacity of 50 paneled beds. Each control was staffed by a medical team consisting of 4 primary care physicians, a hospital specialist physician, as leader of the supervision of medical assistants, discharge management, prescription of treatment and record of the activity in the electronic medical forms. In each control there was a team of 4 nurses and 4 auxiliary technicians. Each control also had its own office of pharmacy. Walking distances were too long for some patients to go to the toilet without developing desaturation. Hoverboard devices attached to wheelchairs were used for the transportation of patients, and portable toilets were set up at strategic points (Figure 2). The hall also had an area for terminally ill patients, where families could accompany their relatives in their final moments, and 4 work areas with offices and a resting area for medical staff.

Hall 9 had a preanalytical area that received samples and prepared them for shipment to a centralized laboratory at a large public hospital. It also had 4 gasometers for basic urgent analysis. There was a radiology area, with two fixed stations for conventional radiology, five portable devices and five portable ultrasound machines. The Army also installed computerized axial tomography equipment outside the hall, which was also accessible from the close Hall 7. This Hall 9 also had an ICU with a capacity of 16 bed equipped with respirators and an intermediate care unit, with another 25 beds to facilitate high-flow, positive-pressure ventilatory support. This unit was actived two weeks after the temporary hospital was opened, with trained medical and nursing staff. Until then, patients who presented a significant deterioration in their clinical situation were transferred in a mobile ICU, available 24 hours a day, to other centers. Deceased patients were evacuated to an external area, also created by the Army, until the mortuary service came to collect the body. Hall 7 was completed on March 30, broadering the capacity to 550 more patients. It had 11 nursing controls each one with a capacity of 50 beds. The central warehouse and the pharmacy were in Hall 10. Some of the materials used were donated by particulars, companies, multinational organizations, and governments.

\section{ASSISTANCE ORGANIZATION}

During the start-up of the hospital, as needs arose, it was necessary to dynamically write a whole series of procedural and operational routines, for example, a discharge routine, deceased routine, orders to pharmacy, and a request for laboratory tests. Thus, more than 30 routines were grouped in a single accessible folder in the electronic medical record. Due to the large number of personnel involved in the project, 


\begin{tabular}{|c|c|c|}
\hline Table 1 & $\begin{array}{l}\text { Criteria for admission in a temporary hospital. IFEMA admission criteria } \\
\text { green) }\end{array}$ & ere on levels 3 and 4 (in \\
\hline Level & Description of clinical profile & Criteria for temporary hospital admission \\
\hline Level 1 & $\begin{array}{l}\text { Patients with criteria for immediate ICU evaluation, } 02 \text { saturation } \leq 94 \% \text { with mask-reservoir, respiratory rate } \\
>30 \mathrm{rpm} \text {, hemodynamic instability, altered level of consciousness without other explanation and good baseline } \\
\text { status. }\end{array}$ & Does not meet criteria \\
\hline Level 2 & $\begin{array}{l}\text { Patient is a candidate for admission to the ICU if presents poor evolution, at the time of assessment has high } \\
\text { oxygen therapy requirements, as well as analytical and radiographic factors of poor prognosis. Requires close } \\
\text { monitoring and possible intensification of treatment. }\end{array}$ & Does not meet criteria \\
\hline Level 3 & $\begin{array}{l}\text { The patient is not a candidate for admission to the ICU, presents high oxygen therapy requirements, as well as } \\
\text { analytical and radiographic factors of poor prognosis. In case of complications or poor evolution, he would be a } \\
\text { candidate for therapeutic deintensification guaranteeing palliative care (symptomatic and emotional control). }\end{array}$ & Meet criteria \\
\hline Level 4 & $\begin{array}{l}\text { Patient at low risk of admission to the ICU due to clinical stability, regardless of baseline condition or prognosis } \\
\text { unrelated to COVID infection. }\end{array}$ & Meet criteria \\
\hline Level 5 & Patients without hospital admission criteria & No admission required \\
\hline
\end{tabular}

the communication and transmission system was essential. In addition to the written documents for routines or protocols, accessible to all staff and periodically reviewed by the steering group, regular meetings were established to convey organizational and clinical information. Informal channels such as WhatsApp texting were also used.

Medical records and admission criteria. Hospital admission was not open to the public. All patients were referred form another hospital, many of them were transported in medicalized vehicles, or even in Army buses, from emergency services of different hospitals. Admission exercised administrative and archival functions for the documentation and was coordinated by the out-of-hospital emergency teams in Madrid. They oversaw capturing information on all patients who entered, filling the electronic medical records. Prior to the installation and start-up of the electronic medical record (Selene ${ }^{\odot}$, Siemens), which took 4 days, the entire procedure was done on paper and had to be physically filed. Later, these procedures were completed online. Patients were identified with a barcode on a bracelet that was issued on Admission, as in any hospital in Madrid. The electronic medical record was configured as forms to facilitate and standardize patient management in a setting with a highly heterogeneous group of doctors (almost all volunteers) with different backgrounds. It was created as follows: an admissions form, a history and clinical evolution form, an electronic pharmaceutical prescription template and a registration form.

For triage, 5 levels of severity from original hospital were established (Table 1): Group 1: healthy patients who needed intensive care from the beginning; Group 2: patients without severe comorbidities but with high probability of ICU admission because of gasometrical, analytical or radiographical factors of poor outcome; Group 3: patients comorbidities or terminal condition that made them not candidates for admission to the ICU, with poor prognostic analytical, gasometrical or radiographic parameters. In case of poor evolution, they would be candidate for therapeutic de-intensification, guaranteeing palliative care (symptomatic and emotional control); Group 4: patient with low risk of admission to the ICU due to clinical stability, regardless of their baseline situation or prognosis unrelated to COVID-19; Group 5: patients without hospital admission criteria. IFEMA admission criteria only included groups 3 and 4.

Human resources, training, and research. The working methodology was established in morning and afternoon shifts, and the nights were covered by 4 doctors from the out-of-hospital emergency teams in Madrid and two hospital doctors. There were 392 doctors, 260 of them primary care physicians and 120 hospital consultants from various specialties (mostly internists, but also clinical microbiologists, oncologists, pediatricians, gastroenterologists, cardiologists, geriatricians, general surgeons and traumatologists), 26 from out-of-hospital emergency teams in Madrid and 25 recently licensed medical doctors who were working as informants for families. There were also 436 nurses (353 in primary care), 357 clinical assistants and 228 guards, and radiology and laboratory technicians were hired. The ICU included a team of specialists in intensive care and residents in this specialty and from the last year in cardiology. While the hospital was in use, the structures and initiatives of a mature hospital were also launched, such as: clinical sessions for the two work shifts on aspects of treatment, portable ultrasounds, ventilatory therapy, epidemiology, and virus behavior, research projects internally or associated with prestigious scientific entities and organizations, clinical commissions such as the pharmacy commission and the management commission and a library for patients.

Therapeutic strategies. The different treatment schemes were protocolized following the scarce clinical ev- 

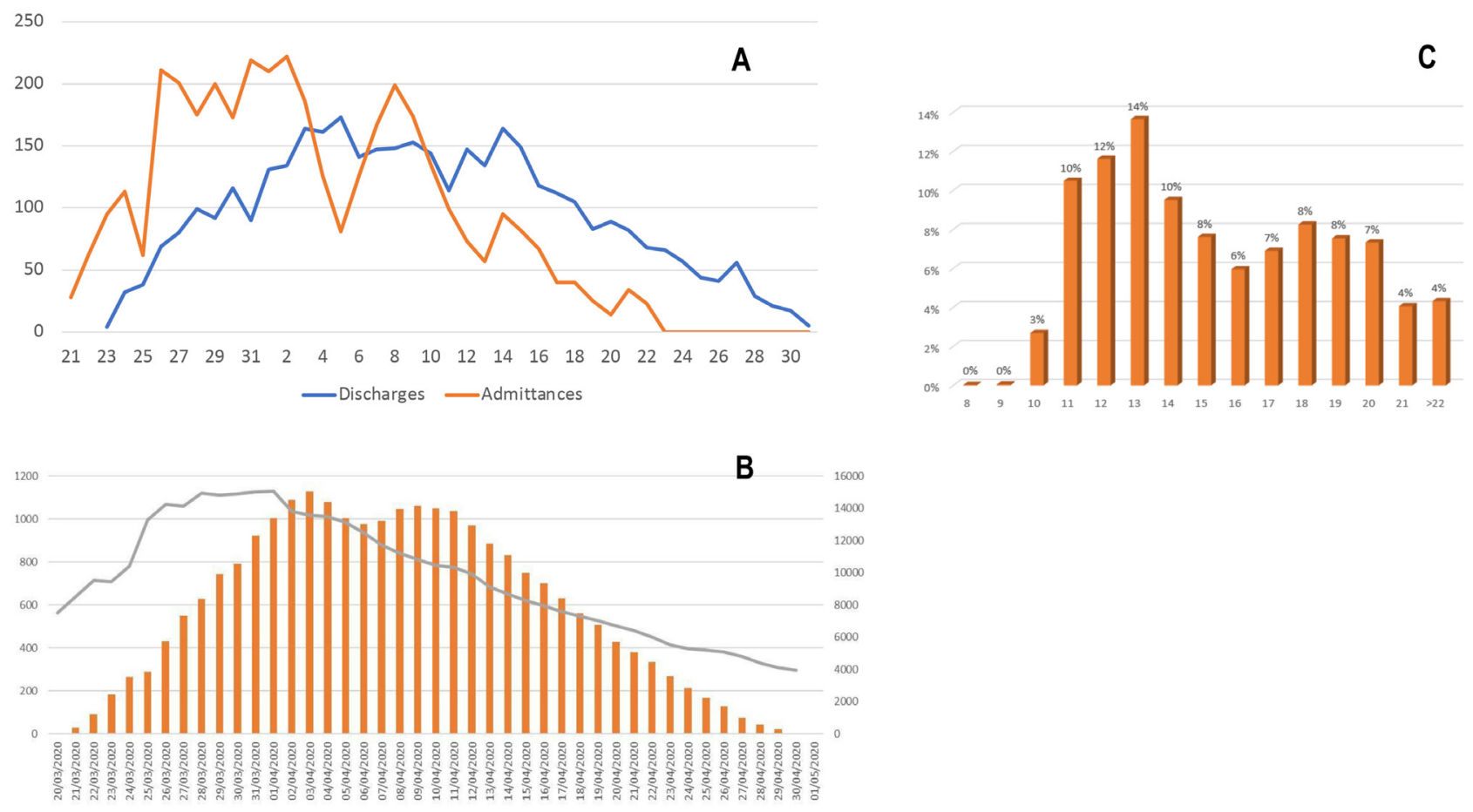

Figure 3 Activity of the Covid-19 IFEMA Field Hospital during the first wave. A: Proportion of Admittances and Discharges from march to April 2020. B: Proportion of Admittances in IFEMA (orange bars) compared with those on the rest of Madrid Hospitals. C: Schedule of IFEMA daily time admittances.

idence available at the time: antiviral treatments (hydroxychloroquine, lopinavir-ritonavir, azithromycin, tocilizumab) [8-14], steroids (dexamethasone, metyl-prednisolone), antibiotic therapy, anticoagulants, ventilation aid maneuvers (patient pronation) or alternative devices for increasing PEEP [7]. A specific location was designated for terminally ill patients, with 4 locations in each ward that allowed access to family members.

Information to families. An information service was also created from the beginning for families; this service was provided by doctors, who were all volunteers who had passed the National Examination Admittance Test for specialized medical training. Upon admission, since visits were prohibited, patients were asked permission to give information to their relatives and asked to assign the interlocutor. Family members were only informed when permission had been given. The information system consisted of reviewing the comments in the electronic medical record as they evolved; the content was concise but complete. The number of contacts with family members reached over 700 per day. The information service was connected to psychological assistance, that was offered when it was requested from the responsible doctor or nurse or the informant himself. It was provided to $100 \%$ of the families in case of deceased.

\section{MAIN CLINICAL RESULTS OF ACTIVITY}

After 5 days of work, the first two wards had the capacity to receive 930 patients, making IFEMA the third largest hospital in Madrid. Although the initial objective was to create a temporary hospital with a 5,000 beds capacity, only the first phase had to be activated. On March 31, an occupancy of 1,300 beds was reached, making it the largest hospital in the Region, and first dedicated exclusively to COVID-19 patients. After 15 days, more than 2,500 admissions had been received, and more than 1,500 discharges had been registered. The admitted patients came from the emergency departments of the different hospitals in Madrid. Patients admitted at the temporary hospital had to meet specific clinical criteria related to their prognosis, as measured by comorbidity and oxygen requirements, in which admission to the ICU would not be expected. Admissions took place between $8 \mathrm{am}$ and $11 \mathrm{pm}$ at any time of the day and for more than 15 days it was the hospital with the highest rate of admissions in the city (Figure 3).

For the duration of activity, 3,817 mild to moderate patients were hospitalized. A $61 \%$ of patients had no score points in Charlson index, 16\% had 1 point, 10\% had 2 points and 10\% had 3 points. Patients with dependency were excluded from admission because of the care logistics required by this clinical profile could not be provided. Ninety-one percent had a diagnosis of pneumonia ( $53 \%$ were bilateral). the remaining were patients with Covid-19 symptoms and oxygen saturation less 
than $91 \%$. Many of them developed the lung infiltrate within 48 hours. The median of duration of stay was 5 days, with the longest admittance lasting 36 days. The most frequent comorbidities were hypertension (16.5\%), diabetes (9.1\%), COPD $(6 \%)$, asthma (4.6\%), obesity $(2.9 \%)$ and dementia (1.6\%). Regarding the treatment administered during admission $60 \%$ of patients received hydroxychloroquine, 24\% lopinavir/ritonavir combination, 15\% azithromycin and 2.4\% corticosteroids (three of them not actually approved by FDA for use against COVID-19 as azithromycin, hydroxychloroquine, or lopinavir/ritonavir combination). A total of 113 patients (3\%) were transferred to another center due to aggravation, $19(0.5 \%)$ were admitted to ICU and 16 patients (0.4\%) died. Estimate the costs of IFEMA temporary hospital is complex, more so in the situation of the first pandemic wave. Including the rental of a facility with infrastructure already in place (toilets, air conditioning and recirculating, connectivity and easy access) for several months, the costs for bulkheads and PVC plates, and the fusion work for more than $30 \mathrm{~km}$ of copper pipe to guarantee the flow and pressure of oxygen, the full estimate cost was around 18 million euros [15].

\section{DISCUSSION AND REVIEW}

One key element to reducing the overload of care in large hospitals during peak health emergencies lies in the development of flexible structures capable of absorbing the surplus of patients. These temporary hospitals should define criteria for admitting patients of moderate intensity, guaranteeing their safety in care, helping to break the domestic transmission and, if possible, attending to patients' social and emotional care needs [16].

Perhaps the most efficient model is the conversion of existing structures with the capacity to accommodate crowds, an example of which is the fairgrounds. This is usually built in a large area, well communicated for the transport of patients and clinical logistics. The fairgrounds have broad spaces that include administration areas, restrooms, climatization, pre-installations to incorporate portable equipment, telephony, and internet connection via cable and Wi-Fi. They usually have high ceilings for better control of recirculation of air and lower risk of viral spread. Most of them comply with the recommendations on replacement, ventilation, temperature-humidity control and air recirculation [17], although not specific to COVID-19 [18]. In a hall, there can be areas for patients, beds and trolleys to pass through, as well as dirty circuits for waste disposal. In addition, areas can be separated for patients to walk around, reducing the risk of thromboembolic disease, and where they can monitor desaturation themselves. The construction of the care units, with incomplete boxes, although detracting from privacy, allows patients to interact and monitor each other. This helps them manage the emotional and social component to recover and thrive during a period that, would otherwise, be disruptive to their lives. All this deployment is inexpensive, quick, and easy to set up.

As in IFEMA, UK opted for the fairgrounds. The Nightin- gale program consisted of 7 centers. The largest were the one in Birmingham and the ExCeL in London (Exhibition Center of London), both with 4,000 beds and the latter with 500 ICU beds, probably the largest in Europe. Two in Bristol and Manchester of 1,000 beds each and another three in Sunderland, Harrogate, and Exeter of about 500. All were open during the first wave, although only the one in London maintained about 50 beds of occupancy. At least the two largest were put on standby and reopened in January for the third wave [19-20]. From May 2020 to the present, some have been reused, such as the one in Exeter for vaccination programs or the one in Bristol for ophthalmology support [21].

The city of Milan, thanks to private donations, built in record time the Field Hospital at the Fiera di Milano, with a capacity of 1,200 beds, 200 of them for critical patients [22]. Hospitals with the same characteristics were built in the fairgrounds of the main cities of the world, such as the Javits in New York with a capacity for 2,500 beds and 1,090 patients studied [23], the one in Stockholm, Teheran, etc. Although some of them did not open, such as the Messe in Berlin (1,000 beds and 330 ICU) [24], they are currently awaiting new openings to provide their services. Other large-scale structures that have been converted include indoor stadiums $[25,26]$, sports centers and ice palaces, such as the one in Moscow with more than 2,000 beds and over 1,000 inpatients treated [27].

The next most widely used model has been the field hospital, either made of canvas, plastic or inflatable materials. This solution has allowed building hospitals in central areas of difficult communication (Central Park Hospital with more than 450 beds) [28] or in cities where there were no previous structures (Pachuca Hospital in Mexico with a capacity for 1,000 people) [29]. It has also been the most used formula to increase capacity in the hospitals themselves (parking lots, etc.), where tents were built to carry out massive diagnostic tests or beds with oxygen support were set up taking advantage of the supply stations of the hospitals themselves, for example, Hospital La Paz in Madrid or La Fe in Valencia.

The third model employed has been the outfitting of shipping hospitals such as the USNS Comfort (T-AH-20) docked in Manhattan or the USNS Mercy in Los Angeles. Both ships have a capacity of 1,000 patients and 80 ICU beds. Smaller ships with a capacity of about 450 persons have been chartered, such as the Splendid. These solutions have less physical space between patients, which limits ambulation and facilitates transmission, but have the advantage of mobility that allows them to serve large coastal areas [30].

The biggest challenge is the construction of new hospitals designed for the treatment of infectious diseases. Examples of this are centers such as Huoshenshan or Leishenshan in Wuhan, built in 10 days and with a capacity for more than 2,000 people, the one in Zhengzhou with a capacity for 800 or other smaller ones such as Fuqing or Weihai with less than 400 [31]. Prefabricated modular hospitals with a smaller capacity $(250$ patients) have also been built. The design of these hospitals contemplates the sectorization by pavilions and Halls in the 


\begin{tabular}{|c|c|c|c|c|}
\hline Table 2 & \multicolumn{4}{|c|}{$\begin{array}{l}\text { Average estimate of beds in temporary hospitals. In case of need, most } \\
\text { semi-critical beds are equipped with ventilatory support equipment, } \\
\text { so that both percentages could be added together. }\end{array}$} \\
\hline \multicolumn{2}{|c|}{ Type of temporary hospital } & Total beds & Semicritical beds & Critics' beds \\
\hline \multicolumn{2}{|c|}{ Field hospital (Tents) } & $250-500$ & $12(2-4 \%)$ & $12(2-4 \%)$ \\
\hline \multicolumn{2}{|c|}{ Sports centers, stadiums } & $250-500$ & $10(2-4 \%)$ & $10(2-4 \%)$ \\
\hline \multicolumn{2}{|c|}{ Shipping Hospitals } & $450-1000$ & $20(2-5 \%)$ & $20(2-5 \%)$ \\
\hline \multicolumn{2}{|c|}{ Exhibition centers } & $800-1300$ & $20-30(2-6 \%)$ & $20(2-4 \%)$ \\
\hline \multicolumn{2}{|c|}{ Built Emergency Hospitals } & $1000-2000$ & $30(1.5-3 \%)$ & $20(1-2 \%)$ \\
\hline
\end{tabular}

care areas, access circuits and the pre-installation of any clinical equipment, beyond those necessary for patient's care. This allows the reuse of the facility for other public health purposes, from vaccination or radiological screening centers to the implementation of hybrid operating rooms to alleviate the surgical waiting list. This versatility has been developed in the Emergency Hospital Enfermera Isabel Zendal in Madrid [32], completed at the end of the second wave, with 1,056 beds, 20 of them for critical care and another 30 for convertible semi-critical care. It has a laboratory, radiology area, heliport, and easy road access. It is currently open with more than 2,300 patients discharged. At present, it is a COVID monographic center, offering excellent performance in ventilatory support, however, it is designed for multipurpose functions and represents the paradigm of Healthcare adaptation and investment in public health.

The two critical decisions in the management of patients with COVID-19 admitted to temporary hospitals are the delimitation of the clinical profile of the candidate patient admitted to these structures and the ratio of these patients who may require, during admission, assistance in the critical care area. There are several levels of care for COVID-19 patients. These include comorbidity and oxygen requirements, because the need for an ICU bed and the prognosis depend on them. These are described above (Table 1). The patients who are candidates for admission to these centers should be those with a low risk of admission to the ICU due to clinical stability (regardless of comorbidity), but also those who are not candidates for admission to the ICU due to poor prognosis. In case of poor evolution, these patients would receive therapeutic deintensification guaranteeing palliative care (symptomatic and emotional control). Patients with a good baseline situation and high oxygen requirements, who might require admission to the critical care unit, should not be admitted to these centers. Patients admitted to these centers should meet, at the time of admission, the condition of diagnostic confirmation of COVID-19, an advanced clinical triage that places patients in levels 3 and 4 and a negative influenza virus test, to avoid nosocomial transmission. The history of home oxygen therapy would be less limiting factor for admission in a temporary hospital than functional dependence or frailty. Finally, these centers are also useful for patients whose liv- ing conditions at home do not allow blocking the domestic chain of transmission. Medicalized hotels are also useful for this purpose.

The ratio of ICU beds/total beds in these temporary centers is around $5 \%$, rising to $8-10 \%$ if we add the semicritical area (Table 2), where intermediate ventilatory measures such as CPAPs and other devices that guarantee PEEP and high oxygen flow (7) are initiated. Most of the semi-critical beds are equipped with ventilation equipment and can be transformed into critical care beds. Exceptions with a higher proportion of ICU beds are described, such as La Messe in Berlin, the Nightingale in London and the Fiera di Milano, which could probably also accept level 2 patients, but which we cannot evaluate because they have not been fully operational. At IFEMA, once the ICU was built, the bed ratio was balanced for patient care. However, there were two fully equipped mobile ICUs parked at the main entrances and ready to transfer patients in case there was a sudden increase in demand in the critical care area. The success of the critical care units depends entirely on the clinical criteria for admission to the center.

According to health experts, the first wave of the COVID-19 pandemic tested the resilience of the Spanish health system [33], especially in Madrid, which has a high degree of social interaction and the highest population density in Spain (834 inhabitants $/ \mathrm{km}^{2}$ in 2019). Furthermore, where they are the oldest population in Europe [34]. In this context, temporary hospitals could be an example of flexibility and adaptation.

As a conclusion, we think that the key to reducing the overload of care in large hospitals during peaks of health emergencies lies in the development of flexible structures capable of absorbing the excess of patients. These temporary hospitals must ensure safety in care, breaking domestic transmission and attending to the social and emotional needs of patients. The most frequently developed model throughout the world has been the conversion of fairgrounds into medical facilities. The average capacity of such structures is around 1,000 beds with a proportion of $5-8 \%$ of ICU beds, including semi-critical beds that could be converted. The success of these healthcare structures depends on the delimitation of admission criteria and the proportion of these patients who may require, during their admission, assistance in the critical care area. 


\section{ACKNOWLEDGEMENTS}

To the city of Madrid, to the many health-care volunteers, to the out-of-hospital emergency services and to the armed forces. The success of this hospital is entirely yours.

\section{CONFLICTS OF INTEREST}

All authors declare they have no conflicts of interest.

\section{REFERENCES}

1. Chen N, Zhou M, Dong X, Qu J, Gong F, Han Y, et al. Epidemiological and clinical characteristics of 99 cases of 2019 novel coronavirus pneumonia in Wuhan, China: a descriptive study. Lancet. 2020 Feb 15;395(10223):507-13.

2. Coronavirus disease (COVID-19) Situation in numbers (by WHO Region) [Internet]. 2021. Available from: https://www.who.int/emergencies/diseases/novel-coronavirus-2019

3. Spain Becomes Latest Epicenter of Coronavirus After a Faltering Response - The New York Times [Internet]. [cited 2020 May 4]. Available from: https://www.nytimes.com/2020/03/13/world/ europe/spain-coronavirus-emergency.html?action=click\&tmodule $=$ Related Linkstipgtype $=$ Article

4. Observatorio de Resultados. Séptimo Informe de Hospitales, 2016- 2018. Available from: http://www.madrid.org/bvirtual/ BVCM020357.pdf

5. Martín MC, León C, Cuñat J, del Nogal F. Recursos estructurales de los Servicios de Medicina Intensiva en España. Med Intensiva. 2013;37(7):443-51.

6. Shen Y, Cui Y, Li Ning, Tian C, Chen M, Ye, et al. Emergency Responses to Covid-19 Outbreak: Experiences and Lessons from a General Hospital in Nanjing, China. Cardiovasc Interv Radiol, 2020 May 2; doi: /10.1007/s00270-020-02474-w

7. Mateos-Rodríguez A, Ortega-Anselmi J, Candel-González FJ, Canora-Lebrato J, Fragiel-Saavedra M, Hernández-Píriz A, Behzadi-Koocahni N, González-Del Castillo J, Pérez-Alonso A, de la Cruz-Conty ML, García-de Casasola G, Marco-Martínez J, Zapatero-Gaviria A. Alternative CPAP methods for the treatment of secondary serious respiratory failure due to pneumonia by COVID-19. Med Clin (Barc). 2020 Nov 6:S0025-7753(20)30732-6.. doi: 10.1016/j.medcli.2020.09.006.

8. Vincent MJ, Bergeron E, Benjannet S, Erickson BR, Rollin PE, Ksiazek TG, et al. "Chloroquine is a potent inhibitor of SARS coronavirus infection and spread" J. Virol 2005; 2: 69.

9. Yao X, Ye F, Zhang M, et al. "In Vitro Antiviral Activity and Projection of Optimized Dosing Design of Hydroxychloroquine for the Treatment of Severe Acute Respiratory Syndrome Coronavirus 2 (SARSCoV-2)". Clin Infec Dis. 2020, March 9. Doi: 10.1093/cid/ciaa237

10. Deng L, Li C, Zeng $\mathrm{O}$, Liu $\mathrm{X}$, Li $\mathrm{X}$, Zhang $\mathrm{H}$ et al. "Arbidol combined with $L P V / r$ versus LPV/r alone against Corona Virus Disease 2019: a retrospective cohort study. J Infect. 2020. doi:10.1016/j. jinf.2020.03.002
11. Liu K, Chen Y, Lin R, Han K. "Clinical feature of COVID-19 in elderly patients: a comparison with young and middle-aged patients". J Infect. 2020 Mar 11. pii: S0163-4453(20)30116-X. doi: 10.1016/j.jinf.2020.03.005.

12. Sheahan TP, Sims $A C$, Leist $S R$, Schäfer $A$, Won J, Brown $A J$, et al. Comparative therapeutic efficacy of remdesivir and combination lopinavir, ritonavir, and interferon beta against MERS-CoV. Nat Commun 2020; 11: 222.

13. Gautret $P$, Lagier JC, Parola $P$, Hoang VT, Meddeb $L$, Mailhe $M$, Doudier B, Courjon J, Giordanengo V, Vieira VE, Tissot Dupont $H_{\text {, }}$ Honoré S, Colson P, Chabrière E, La Scola B, Rolain JM, Brouqui P, Raoult D. Hydroxychloroquine and azithromycin as a treatment of COVID-19: results of an open-label non-randomized clinical trial. Int J Antimicrob Agents. 2020;56(1):105949. doi: 10.1016/j.ijantimicag.2020.105949.

14. Fu B, Xu X, Wei H. Why tocilizumab could be an effective treatment for severe COVID-19? J Transl Med. 2020 Apr 14;18(1):164. doi: 10.1186/s12967-020-02339-3.

15. https://www.comunidad.madrid/noticias/2020/04/28/invertimos-185-millones-equipamiento-mantenimiento-hospital-temporal

16. Chen $S$, Zhang Z, Yang J, Wang J, Zhai $X$, Bärnighausen T, Wang C. Fangcang shelter hospitals: a novel concept for responding to public health emergencies. Lancet. 2020 Apr 18;395(10232):13051314. doi: 10.1016/S0140-6736(20)30744-3.

17. Ashrae. ASHRAE Position Document on Infectious Aerosols [Internet]. 2020. Available from: www.ashrae.org, Hierarchy of Controls | NIOSH | CDC [Internet]. [cited 2020 0ct 9]. Available from: https:|| www.cdc.gov/niosh/topics/hierarchy/default.html

18. REHVA COVID-19 guidance document, How to operate and use building services in order to prevent the spread of the coronavirus disease (COVID-19) virus (SARS-CoV-2) in workplaces. 2020 available at: https://www.rehva.eu/fileadmin/user_upload/REHVA_COVID-19_guidance_document_ver2_20200403_1.pdf

19. Michael Day. "Covid-19: Nightingale hospitals set to shut down after seeing few patients". BMJ. 2020 May 7;369:m1860. doi: 10.1136/bmj.m1860

20. Wise J. Covid-19: London's Nightingale Hospital will reopen for non-covid cases. BMJ. 2021 Jan 5;372:n15. doi: 10.1136/bmj.n15. PMID: 33402358.

21. COVID-19 hospitals in the United Kingdom, available at: https:// en.wikipedia.org/wiki/COVID-19_hospitals_in_the_United_Kingdom

22. FieraMilanoCity Repurposed into a Temporary Hospital in 10 Days. Available at: http://emag.archiexpo.com/covid-19-fieramilanocity-repurposed-into-a-temporary-hospital-in-10-days/

23. Inside First 1,000-Bed Temporary Hospital at Jacob K. Javits Convention Center. Available at: https://www.rollingstone.com/politics/politics-pictures/covid-19-javits-convention-center-overflow-hospital-974703/javits-018/

24. Corona Hospital: Exhibition hall becomes Covid 19 Clinic. Available at: https://www.berlin.de/en/news/coronavirus/6128231-6098215-corona-hospital-exhibition-hall-becomes-.en.html

25. São Paulo stadium turning into hospital for coronavirus. Availa- 
ble at: https://www.chicagotribune.com/coronavirus/sns-sao-paulo-stadium-coronavirus-outbreak-hospital-20200323-5xcbavvxnnfovn7quuqjdfwwkm-story.html

26. Inside Nigeria's 'isolation stadium'. Available at: https://www.bbc. com/sport/africa/52152681

27. Moscow turns ice rink into hospital as Russia's COVID-19 cases hit record. Available at: https://www.reuters.com/article/ us-health-coronavirus-russia-hospital-idUSKBN27W14E

28. Treating Coronavirus in a Central Park 'Hot Zone'. Available at: https://www.nytimes.com/2020/04/15/nyregion/coronavirus-central-park-hospital-tent.html

29. Inflatable hospital installed in Hidalgo before anticipated outbreak. Available at: https://mexiconewsdaily.com/news/coronavirus/inflatable-hospital-installed-in-hidalgo/

30. Hospital ships designated for the COVID-19 pandemic. Available at: https://en.wikipedia.org/wiki/Hospital_ships_designated_for_the_ COVID-19_pandemic

31. A close look at the hospitals in China built to control the COVID-19 pandemic. Available at: https://www.plataformaarquitectura.cl/ cl/937687/una-mirada-de-cerca-a-los-hospitales-en-china-construidos-para-controlar-la-pandemia-del-covid-19

32. Hospital de Emergencias Enfermera Isabel Zendal. https://es.wikipedia.org/wiki/Hospital_de_Emergencias_Enfermera_Isabel_Zendal

33. The Lancet Public Health Editorial. COVID-19 in Spain: a predictable storm? The Lancet Public Health 2020; 5 (11). doi: 10.1016/S24682667(20)30239-5

34. María José Sierra Moros, Susana Monge, Berta Suarez Rodríguez, Lucía García San Miguel, Fernando Simón Soria, et al. "COVID-19 in Spain: view from the eye of the storm". The Lancet Public Health 2020; S2468-2667(20)30286-3. doi: 10.1016/S24682667(20)30286-3. 